\title{
Pengaruh Panjang dan Diameter Stek Batang Terhadap Pertumbuhan Bibit Kelor (Moringa oleifera Lam.)
}

\section{The Influence of the Length and Diameter of Stem Cuttings on Growth of Drumstick (Moringa oleifera Lam.) Seedlings}

\author{
Wahyu Astiko $^{1 *}$, Ahsani Taqwim ${ }^{2)}$, Bambang Budi Santoso ${ }^{3)}$ \\ 1) Program Studi Agroekoteknologi Fakultas Pertanian, Universitas Mataram \\ 2) Alumni Program Studi Agroekoteknologi Fakultas Pertanian, Universitas Mataram \\ 3) Kelompok Peneliti Pertanian Lahan Kering Fakultas Pertanian, Universitas Mataram \\ *corresponding author, email: astiko@unram.ac.id
}

Manuscript received: 25-10-2018. Accepted: 12-11-2018

\begin{abstract}
ABSTRAK
Penelitian ini bertujuan mengetahui ukuran panjang dan diameter stek batang yang baik menghasilkan bibit kelor (Moringa oleifera Lam.). Penelitian dilaksanakan pada MaretMei 2017 di lahan pembibitan berlokasi di Dasan Agung, Mataram, dengan ketinggian tempat 16 meter dpl. Metode yang digunakan adalah metode eksperimental dengan Rancangan Acak Lengkap dengan 3 ulangan dan masing-masing ulangan dipersiapkan 5 unit serial unit percobaan. Perlakuan panjang stek $25 \mathrm{~cm}, 50 \mathrm{~cm}$, dan $75 \mathrm{~cm}$ dikombinasikan dengan diameter stek 3-4 cm, 4,1-5 cm, dan 5,1-6 cm. Hasil penelitian menunjukkan bahwa kombinasi panjang stek $75 \mathrm{~cm}$ dan diameter stek 5,1-6 cm menghasilkan bibit yang berkualitas baik. Semakin panjang stek (hingga $75 \mathrm{~cm}$ ) dan juga semakin tebal diameter stek (5,1-6 cm) pertumbuhan bibit semakin baik.
\end{abstract}

Kata kunci: bibit kelor, diameter stek, panjang stek, stek batang.

\begin{abstract}
The purpose of the study is to discover the best length and the diameter of Moringa oleifera Lam. stem cuttings to produce high quality of seedlings. The study was conducted during March-May 2017 located in the nursery field at Dasan Agung, Mataram, $16 \mathrm{~m}$ asl. This study was experimental research with Complete Randomized Design with three three replications, and each contains 5 serial experiment units. The treatment for stem cutting length $(25 \mathrm{~cm}, 50 \mathrm{~cm}$, and $75 \mathrm{~cm})$ was then combined with different stem cutting diameters (3-4 cm, 4.1-5 cm, and 5.1-6 cm). The result shows that combination of $75 \mathrm{~cm}$ stem length with stem diameter of 5.1-6 cm resulted to have the best seedling growth. The longer the cutting (up to $75 \mathrm{~cm}$ ), the better the growth of the seedling. The thickest stem diameter (5.1-6 $\mathrm{cm})$ resulted better seedling.
\end{abstract}

Keywords: stem diameter, seedling, stem length, stem cutting 


\section{PENDAHULUAN}

Indonesia memiliki banyak potensi keanekaragaman hayati yang telah dimanfaatkan oleh nenek moyang kita. Salah satu keanekaragaman hayati tersebut berupa tanaman yang biasa dimanfaatkan dan mudah dibudidayakan yaitu tanaman kelor (Moringa oleifera Lam.). Habitus tanaman kelor dapat mencapai 10 meter, berbatang lunak, dan daun berukuran kecil berbentuk bulat telur. Berbunga sepanjang tahun, berwarna putih, buah bersisi segitiga dengan panjang sekitar $30 \mathrm{~cm}$ dan dapat tumbuh di dataran rendah sampai ketinggian $700 \mathrm{~m}$ di atas permukaan laut (Ramachandran et al., 1980; Morton, 1991; Fuglie dan Sreeja, 2005).

Tanaman kelor, terutama daun dan buah memiliki nilai gizi tinggi, bermanfaat bagi kesehatan, dan digemari untuk diolah menjadi berbagai jenis sayuran. Olahan sayur daun kelor kaya nutrisi yang bermanfaat bagi pemenuhan asupan gizi keluarga. Kecukupan asupan nutrisi dari sayuran ini sangat diperlukan karena mengandung berbagai vitamin dan mineral yang sangat dibutuhkan bagi kesehatan tubuh manusia. Oleh karena itu, daun kelor memiliki potensi yang sangat baik untuk melengkapi kebutuhan nutrisi dalam tubuh, tercukupinya energi, dan ketahanan tubuh. Hal ini disebabkan daun kelor kaya $\beta$-karoten, protein, vitamin $\mathrm{C}$, kalsium dan kalium, serta sebagai antioksidan alami seperti asam askorbat, flavonoid, fenolat dan karotenoid (Dillard dan Jerman, 2000; Siddhuraju dan Becker, 2003).

Salah satu cara yang menjanjikan untuk meningkatkan produksi sayuran daun kelor adalah perlunya penyediaan bibit yang diperbanyak dengan menggunakan stek batang. Hal ini dikarenakan berbagai keuntungan yang diperoleh yaitu stek yang dibutuhkan relatif sedikit, namun dapat menghasilkan bibit tanaman yang banyak, tanaman yang dihasilkan mempunyai persamaan umur, ukuran dan sifat tanaman yang sama dengan induknya, serta dapat diperoleh dalam waktu yang relatif singkat (Wudianto, 2003).

Perbanyakan dengan stek batang cenderung memberikan produksi biomassa yang lebih banyak karena tanaman cenderung menghasilkan banyak cabang yang rimbun (Hartman et al., 2002). Stek batang yang digunakan sebaiknya berasal dari tanaman yang sehat dan berumur antara 15-20 tahun. Ukuran stek berpengaruh terhadap keberhasilan perbanyakan tanaman. Semakin besar lingkaran stek batang semakin besar peluangnya untuk hidup. Hal ini disebabkan kontribusi perbedaan akumulasi karbohidrat pada bagian bawah stek dan jumlahnya akan optimal untuk pembentukan akar pada stek yang panjang dibandingkan stek pendek (Hartman et al., 2002). Hasil terbaik pada kasus jarak pagar (Jatropha curcas L.) dilaporkan oleh Mahmud et al. (2006) menggunakan stek batang dengan panjang $25 \mathrm{~cm}$ dan diameter 1-3 cm, dan Hariyadi (2006) menggunakan panjang stek batang $25 \mathrm{~cm}$ dan diameter berkisar 1-2 cm, atau panjang 40-50 $\mathrm{cm}$ dengan diameter 1,5-2,5 cm (Deptan, 2006), sedangkan Sardjoko (2006) menggunakan panjang antara $20-30 \mathrm{~cm}$ dan diameter $1-3 \mathrm{~cm}$. Santoso (2010) melaporkan bahwa bibit jarak pagar dengan daya adaptasi yang baik setelah pindah tanam di lapangan berukuran panjang berkisar 20-30 cm dengan diameter 2,5-3,0 cm atau dengan diameter 2,0-2,4 cm atau 2,5-2,9 cm dengan panjang stek $30 \mathrm{~cm}$.

Khusus untuk tanaman kelor, informasi penggunaan panjang dan diameter stek batang belum banyak dipublikasi. Artikel ini memaparkan hasil penelitian yang bertujuan mengetahui panjang dan diameter stek batang yang cocok untuk mendapatkan bibit kelor berkualitas melalui perbanyakan secara vegetatif. 


\section{BAHAN DAN METODE}

Metode yang digunakan dalam penelitian ini adalah metode eksperimental yang dilaksanakan pada bulan Maret-Mei 2017 di lahan pembibitan yang berlokasi di Dasan Agung, Mataram, pada ketinggian tempat 16 meter dpl. Letak posisi geografis $08^{\circ} 33^{\prime}-08^{\circ}$ $38^{\prime}$ Lintang Selatan dan $116^{\circ} 04^{\prime}-116^{\circ} 10^{\prime}$ Bujur Timur. Keadaan mikro klimat di areal penelitian sebagai berikut: kelembaban $83 \%$, suhu 26.6-27.1 ${ }^{\circ} \mathrm{C}$, dan curah hujan berkisar antar 96-150 mm. Percobaan diatur menggunakan Completely Randomized Design dengan 9 kombinasi perlakuan panjang dan diameter stek batang. Perlakuan panjang stek $25 \mathrm{~cm}, 50$ $\mathrm{cm}$, dan $75 \mathrm{~cm}$ dikombinasikan dengan diameter stek 3-4 cm, 4,1-5 cm, dan 5,1-6 cm. Setiap perlakuan dibuat 3 ulangan dan masing-masing ulangan dipersiapkan 5 unit serial, sehingga diperoleh 135 unit percobaan.

\section{Persiapan media}

Pembuatan media tanam untuk pembibitan kelor dengan menggunakan stek batang terdiri atas campuran tanah, pasir, dan pupuk kandang (kotoran sapi) dengan perbandingan 1:1:2 (v/v). Kemudian media tanam campuran tersebut kemudian dimasukkan ke dalam polybag warna hitam berukuran $25 \times 30 \mathrm{~cm}$. Setelah media campuran dimasukkan dalam polybag, media dalam polybag diabiarkan atau dikering-anginkan kurang lebih selama satu minggu. Polybag berisi media campuran tersebut kemudian diletakkan secara acak diletakkan di bawah naungan paranet hitam (meloloskan cahaya sekitar 70-85 persen. Letak polybag diatur dengan posisi berjarak $5 \mathrm{~cm}$ (dalam barisan) dan $10 \mathrm{~cm}$ (antar barisan).

\section{Persiapan bahan stek}

Pengambilan bahan stek dilakukan dengan cara stek diambil dari pohon induk dengan kriteria mimiliki ukuran dan kisaran umur yang sama atau seragam, yaitu telah berproduksi dan berumur antara 15-20 tahun, tumbuh sehat, berbatang lurus. . Stek batang bahan percobaan diambil dari lahan pekarangan milik petani yang ada di Kabupaten Lombok Utara. Cabang batang calon bahan stek dipotong pada bagian pangkal cabang dengan memperhatikan pemenuhan ukuran diameter yang akan dipelajari. Batang yang diambil adalah bagian tengah, kemudian diukur panjangnya dengan menggunakan meteran dan untuk mengukur diameter batang dengan menggunakan jangka sorong. Setelah itu kemudian batang tersebut dipotong menjadi stek sesuai dengan kombinasi perlakuan

\section{Penanaman stek}

Sebelum menanam stek, terlebih dahulu yang dilakukan yaitu membuat lubang tanam pada polybag dengan kedalaman lubang tanam $15 \mathrm{~cm}$. Setelah membuat lubang tanam, ke dalam lubang tersebut kemudian ditanam (dimasukkan) satu stek dari tiap-tiap perlakuan.

\section{Pemeliharaan}

Pemeliharaan unit pembibitan meliputi penyiraman, pemupukan, penyiangan, penyulaman, serta pengendalian hama dan penyakit. Penyiraman dilakukan satu kali sehari pada pagi hari. Penyiangan dilakukan dua minggu sekali terhadap gulma-gulma yang tumbuh di media pembibitan. Pemupukan dilakukan dengan cara membenamkann pupuk NPK phonska di sekeliling bibit stek pada saat sebelum tanam dan saat bibit stek berumur 14 hari 
sesudah tanam dengan dosis $5 \mathrm{~g} /$ polybag. Penyulaman dilakukan pada bibit stek yang mati. Penyulaman dilakukan dengan cara mengambil bibit stek yang sudah tumbuh pada bibit yang telah dipersiapkan sebagai pengganti (sulaman). Pengendalian hama dan penyakit dilakukan secara mekanik karena jumlah serangannya sedikit. Pemeliharaan dilakukan hingga akhir percobaan atau setelah bibit tanaman kelor berumur 3 bulan dan siap tanam di lapangan.

\section{Observasi dan Analisis data}

Parameter pertumbuhan bibit asal stek batang yang diamati meliputi, saat muncul tunas, jumlah tunas, jumlah daun, bobot tunas segar, bobot kering tunas, jumlah akar, panjang akar, bobot akar segar, bobot kering akar, bobot batang sebelum tumbuh bibit, bobot batang setelah tumbuh bibit. Data terkumpul kemudian dianalisis menggunakan Anova $5 \%$ dan diuji lanjut dengan menggunakan uji BNJ pada taraf 5\% apabila ada pengaruh dari perlakuan.

\section{HASIL DAN PEMBAHASAN}

Hasil penelitian menunjukkan bahwa ukuran panjang stek berpengaruh nyata terhadap pertumbuhan bibit kelor, namun diameter stek dan juga kombinasi panjang dan diameter stek berpengaruh tidak nyata terhadap pertumbuhan bibit kelor. Berdasarkan ringkasan hasil analisis sidik ragam dapat di jelaskan bahwa panjang stek batang berpengaruh nyata terhadap sebagian besar parameter pertumbuhan bibit, kecuali pada bobot segar dan kering tunas berumur 28 HST serta bobot segar dan kering akar berumur 28 HST, panjang stek berpengaruh tidak nyata. Diameter stek batang berpengaruh tidak nyata terhadap sebagian besar komponen pertumbuhan bibit, kecuali pada jumlah tunas berumur 42-84 HST, jumlah daun berumur 70 HST, panjang akar 28 HST, dan bobot stek, diameter stek berpengaruh nyata. Kombinasi panjang dan diameter stek hanya berpengaruh nyata terhadap bobot stek.

\section{Saat Muncul Tunas}

Hasil analisis menunjukkan bahwa terdapat pengaruh nyata panjang stek terhadap saat muncul tunas, sedangkan diameter stek berpengaruh tidak nyata. Tunas yang tumbuh paling awal pada bibit terjadi pada stek dengan panjang $75 \mathrm{~cm}$ (Tabel 1).

Tabel 1. Saat muncul tunas bibit kelor pada berbagai ukuran stek batang.

\begin{tabular}{lc}
\hline Ukuran stek & Saat muncul tunas pertama (hari) \\
\hline Panjang stek (P) & \\
$25 \mathrm{~cm}$ & $11,44 \mathrm{a}$ \\
$50 \mathrm{~cm}$ & $10,22 \mathrm{a}$ \\
$75 \mathrm{~cm}$ & $7,00 \mathrm{~b}$ \\
\hline BNJ 5\% & 1,48 \\
\hline Diameter stek (D) & \\
$3-4$ cm & 9,00 \\
$4,1-5 \mathrm{~cm}$ & 9,33 \\
$5,1-6 \mathrm{~cm}$ & 10,33 \\
\hline BNJ 5\% & - \\
\hline
\end{tabular}

Keterangan: angka-angka pada kolom yang sama yang diikuti dengan huruf yang sama berbeda tidak nyata pada uji BNJ taraf nyata 5\% 
Tabel 1, juga menunjukkan bahwa saat muncul tunas panjang stek $25 \mathrm{~cm}$ berbeda tidak nyata dengan saat muncul tunas panjang stek $50 \mathrm{~cm}$, namun berbeda nyata dengan panjang stek $75 \mathrm{~cm}$. Adapun saat muncul tunas pada panjang stek $50 \mathrm{~cm}$ terhadap panjang stek $75 \mathrm{~cm}$, tampak berbeda nyata.

Adanya perbedaan respon yang nyata saat munculnya tunas pada masing-masing panjang stek diduga karena cadangan zat makanan yang terdapat di dalam organ stek dengan panjang stek $75 \mathrm{~cm}$ mencukupi kebutuhan zat makanan yang dibutuhkan stek untuk pertumbuhannya. Hal tersebut sesuai menurut Hartman et al., (2002), terbentuknya akar dapat lebih dahulu kemudian tunas atau sebaliknya. Jika tunas yang terbentuk lebih dahulu, kondisi ini menggambarkan bahwa dengan tumbuhnya tunas akan membantu tertampungnya suatu senyawa tumbuh dari fotosintat tanaman yang diperlukan untuk pembentukan primordia akar dan proses lebih lanjut dalam mendukung terjadinya pertumbuhan akar.

\section{Jumlah Tunas}

Panjang stek bibit kelor berpengaruh nyata terhadap jumlah tunas bibit kelor nampak umur 14-84 HST, dan berpengaruh nyata diameter stek mulai umur 42-84 HST, namun berpengaruh tidak nyata saat pertumbuhan awal yaitu 14-28 HST. Jumlah tunas bibit pada berbagai umur pengamatan disajikan pada Tabel 2.

Tabel 2. Perkembangan jumlah tunas bibit kelor pada berbagai ukuran stek batang.

\begin{tabular}{|c|c|c|c|c|c|c|}
\hline \multirow{3}{*}{ Ukuran stek } & \multicolumn{6}{|c|}{ jumlah tunas bibit } \\
\hline & \multicolumn{6}{|c|}{ waktu pengamatan (HST) } \\
\hline & 14 & 28 & 42 & 56 & 70 & 84 \\
\hline \multicolumn{7}{|l|}{ Panjang stek $(\mathrm{P})$} \\
\hline $25 \mathrm{~cm}$ & $0,32 \mathrm{c}$ & $0,49 \mathrm{c}$ & $0,64 \mathrm{c}$ & $0,81 \mathrm{c}$ & $1,03 \mathrm{c}$ & $1,16 \mathrm{c}$ \\
\hline $50 \mathrm{~cm}$ & $2,20 \mathrm{~b}$ & $2,48 \mathrm{~b}$ & $2,77 \mathrm{~b}$ & $2,96 \mathrm{~b}$ & $3,21 \mathrm{~b}$ & $3,44 \mathrm{~b}$ \\
\hline $75 \mathrm{~cm}$ & $4,86 \mathrm{a}$ & $5,43 \mathrm{a}$ & $5,60 \mathrm{a}$ & $5,74 \mathrm{a}$ & $6,02 \mathrm{a}$ & $6,13 \mathrm{a}$ \\
\hline BNJ $5 \%$ & 0,87 & 0,66 & 0,61 & 0,59 & 0,60 & 0,57 \\
\hline \multicolumn{7}{|l|}{ Diameter stek (D) } \\
\hline $3-4 \mathrm{~cm}$ & 2,84 & 3,11 & $3,31 \mathrm{a}$ & $3,47 \mathrm{a}$ & $3,75 \mathrm{a}$ & $3,94 \mathrm{a}$ \\
\hline $4,1-5 \mathrm{~cm}$ & 2,39 & 2,77 & $3,03 \mathrm{ab}$ & $3,27 \mathrm{ab}$ & $3,54 \mathrm{ab}$ & $3,68 \mathrm{ab}$ \\
\hline $5,1-6 \mathrm{~cm}$ & 2,16 & 2,52 & $2,67 \mathrm{~b}$ & $2,76 \mathrm{~b}$ & $2,97 \mathrm{~b}$ & $3,12 \mathrm{~b}$ \\
\hline BNJ $5 \%$ & - & - & 0,61 & 0,59 & 0,60 & 0,57 \\
\hline
\end{tabular}

Keterangan: angka-angka yang diikuti huruf yang sama pada kolom yang sama berbeda tidak nyata pada uji BNJ 5\%, HST= Hari Setelah Tanam

Pada Tabel 2, tampak bahwa jumlah tunas pada panjang stek $25 \mathrm{~cm}$ berbeda nyata dengan panjang stek 50 dan $75 \mathrm{~cm}$ dari umur $14-84$ HST. Pada diameter stek $3-4 \mathrm{~cm}$ berbeda tidak nyata dengan diameter stek 4,1 - $5 \mathrm{~cm}$ dan 5,1-6 cm saat berumur 14 dan 28 HST, namun menunjukkan berbeda nyata mulai umur 42-84 HST. Menurut Santoso et al., (2008), bahwa ukuran bahan stek seperti panjang dan diameter batang stek harus menjadi pertimbangan dalam perbanyakan secara vegetatif tanaman, karena hal ini terkait dengan keberadaan bahan cadangan makanan, yang umumnya karbohidrat.

Pengamatan pada 84 HST menunjukkan jumlah tunas berkisar antara 1,16-6,13. Panjang stek 50 dan $75 \mathrm{~cm}$ memperlihatkan jumlah tunas yang lebih banyak dibandingkan panjang stek $25 \mathrm{~cm}$. Semakin panjang stek yang digunakan maka jumlah titik tunas/buku 
yang dimiliki stek semakin banyak untuk pertumbuhan tunasnya. Stek dengan panjang $25 \mathrm{~cm}$ merupakan stek yang memiliki panjang terendah daripada perlakuan lain yang digunakan sehingga memiliki titik tunas/buku tersedia lebih sedikit untuk pertumbuhan tunasnya. Hasil penelitian Setiyawan (2000), menyatakan bahwa perlakuan stek 3 buku memberikan pengaruh nyata terhadap jumlah tunas pada stek bambu ampel hijau.

\section{Jumlah Daun}

Jumlah daun bibit asal stek pada berbagai ukuran disajikan dalam Tabel 3. Dari table tersebut tampak bahwa panjang stek batang berpengaruh nyata terhadap jumlah daun bibit dari umur 14-84 HST, dan diameter stek berpengaruh nyata saat berumur 70-84 HST, namun berpengaruh tidak nyata saat berumur $14,28,42$, dan 56 HST.

Tabel 3. Perkembangan jumlah daun bibit kelor pada berbagai ukuran stek batang.

\begin{tabular}{ccccccc}
\hline \multirow{2}{*}{ Ukuran stek } & \multicolumn{7}{c}{ Jumlah daun bibit } \\
\cline { 2 - 7 } & 14 & 28 & 42 & 56 & 70 & 84 \\
\cline { 2 - 7 } & & & & & & \\
Panjang stek (P) & $0,34 \mathrm{~b}$ & $0,75 \mathrm{~b}$ & $1,35 \mathrm{c}$ & $1,74 \mathrm{c}$ & $2,55 \mathrm{c}$ & $4,03 \mathrm{c}$ \\
$25 \mathrm{~cm}$ & $0,66 \mathrm{~b}$ & $4,78 \mathrm{~b}$ & $11,05 \mathrm{~b}$ & $12,95 \mathrm{~b}$ & $16,26 \mathrm{~b}$ & $20,13 \mathrm{~b}$ \\
$50 \mathrm{~cm}$ & $2,18 \mathrm{a}$ & $17,41 \mathrm{a}$ & $27,40 \mathrm{a}$ & $36,25 \mathrm{a}$ & $41,80 \mathrm{a}$ & $47,24 \mathrm{a}$ \\
$75 \mathrm{~cm}$ & 0,91 & 5,83 & 7,32 & 8,06 & 6,88 & 7,74 \\
\hline BNJ 5 \% & & & & & & \\
\hline Diameter stek (D) & 1,22 & 9,07 & 11,00 & 13,56 & $15,86 \mathrm{~b}$ & $18,51 \mathrm{~b}$ \\
$3-4 \mathrm{~cm}$ & 1,12 & 8,13 & 15,60 & 20,10 & $22,99 \mathrm{a}$ & $26,23 \mathrm{ab}$ \\
$4,1-5 \mathrm{~cm}$ & 0,83 & 5,73 & 13,20 & 17,27 & $21,75 \mathrm{ab}$ & $26,66 \mathrm{a}$ \\
\hline $5,1-6 \mathrm{~cm}$ & - & - & - & - & 6,88 & 7,74 \\
\hline BNJ 5 \% & - & &
\end{tabular}

Keterangan: angka-angka yang diikuti huruf yang sama pada kolom yang sama berbeda tidak nyata pada uji BNJ 5\%, HST= Hari Setelah Tanam

Berdasarkan Tabel 3 di atas tampak jumlah daun bibit kelor pada panjang stek $25 \mathrm{~cm}$ merupakan jumlah daun terendah saat berumur 14-84 HST yakni berturut-turut 0,34, 0,75, $1,35,1,74,2,55$, dan 4,03 helai. Sedangkan jumlah daun bibit kelor pada panjang stek lainnya lebih tinggi yakni saat berumur 14-84 HST jumlah daun berturut-turut, panjang stek $50 \mathrm{~cm}$ $(0,66,4,78,11,05,12,95,16,26$, dan 20,13 helai) dan panjang stek $75 \mathrm{~cm}(2,18,17,41,27,40$, $36,25,41,80$, dan 47,24 helai). Perbedaan jumlah daun ini mengindikasikan bahwa semakin panjang stek yang digunakan, maka jumlah daun yang tumbuh dan berkembang akan semakin meningkat. Hal ini sesuai dengan pendapat Raden (2008), yang melakukan penelitian pada jarak pagar mengungkapkan bahwa semakin tinggi tanaman, maka jumlah daun, luas daun total dan indeks luas daun akan semakin meningkat.

Pada Tabel 3 di atas juga mengindikasikan bahwa ukuran diameter stek berpengaruh nyata terhadap jumlah daun bibit saat berumur 70-84 HST. Hal ini sejalan dengan penelitian Santoso et al., (2008), yang dilaporkan bahwa terhadap komponen tajuk bibit, ukuran diameter stek berpengaruh terhadap jumlah daun, luas daun, dan bobot kering tajuk bibit. Namun dari uraian Tabel 3 di atas juga terlihat jumlah daun pada diameter stek 4,1-5 cm yang awalnya lebih tinggi dari diameter stek 5,1-6 cm saat umur 42-70 HST menjadi lebih rendah saat berumur 84 HST. Hal ini diduga akibat meningkatnya kandungan lignin dan 
kondisi bahan stek yang sudah terlalu berkayu. Meskipun terjadi peningkatan kadar karbohidrat tetapi diikuti dengan tingginya kandungan lignin dan kondisi bahan stek yang sudah terlalu berkayu akan menghambat proses pembentukan tunas menuju perkembangan lebih lanjut menjadi daun (Nurhasybi et al., 2003). Pada penelitian ini fenomena tampak pada tunas-tunas yang mulanya telah tumbuh, namun tidak tampak tumbuh dikemudian harinya, bahkan tampak tunas-tunas tersebut mati.

\section{Jumlah dan Panjang Akar Utama}

Ukuran panjang stek berpengaruh nyata terhadap jumlah dan panjang akar bibit berumur 28, 56, dan 84 HST. Adapun diameter stek terhadap jumlah akar berpengaruh tidak nyata umur 28,56 , dan 84 HST, sedangkan diameter stek terhadap panjang akar berpengaruh nyata pada umur 28, 56, dan 84 HST. Jumlah akar dan panjang akar bibit stek disajikan pada Tabel 4.

Tabel 4. Perkembangan jumlah dan panjang akar utama bibit kelor pada berbagai ukuran stek batang.

\begin{tabular}{|c|c|c|c|c|c|c|}
\hline \multirow{2}{*}{ Ukuran stek } & \multicolumn{3}{|c|}{$\begin{array}{c}\text { Jumlah akar } \\
\text { waktu pengamatan (HST) }\end{array}$} & \multicolumn{3}{|c|}{$\begin{array}{c}\text { Panjang akar }(\mathrm{cm}) \\
\text { waktu pengamatan }(\mathrm{HST})\end{array}$} \\
\hline & 28 & 56 & 84 & 28 & 56 & 84 \\
\hline \multicolumn{7}{|l|}{ Panjang stek $(\mathrm{P})$} \\
\hline $25 \mathrm{~cm}$ & $0,62 \mathrm{~b}$ & $1,50 \mathrm{c}$ & $4,11 \mathrm{c}$ & $0,38 \mathrm{~b}$ & $4,66 \mathrm{~b}$ & $9,09 \mathrm{~b}$ \\
\hline $50 \mathrm{~cm}$ & $3,33 \mathrm{ab}$ & $10,11 \mathrm{~b}$ & $17,22 \mathrm{~b}$ & $0,81 \mathrm{~b}$ & $5,66 \mathrm{ab}$ & $10,39 \mathrm{~b}$ \\
\hline $75 \mathrm{~cm}$ & $9,11 \mathrm{a}$ & $21,11 \mathrm{a}$ & $32,78 \mathrm{a}$ & $2,36 \mathrm{a}$ & $7,09 \mathrm{a}$ & $14,66 \mathrm{a}$ \\
\hline BNJ 5\% & 5,81 & 7,92 & 10,08 & 0,63 & 1,82 & 2,57 \\
\hline \multicolumn{7}{|l|}{ Diameter stek (D) } \\
\hline $3-4 \mathrm{~cm}$ & 4,52 & 9,67 & 18,11 & $1,01 \mathrm{~b}$ & $6,15 \mathrm{ab}$ & $12,54 \mathrm{a}$ \\
\hline $4,1-5 \mathrm{~cm}$ & 4,66 & 13,67 & 17,33 & $1,74 \mathrm{a}$ & $6,57 \mathrm{a}$ & $11,82 \mathrm{ab}$ \\
\hline $5,1-6 \mathrm{~cm}$ & 3,88 & 9,39 & 18,67 & $0,80 \mathrm{~b}$ & $4,69 \mathrm{~b}$ & $9,79 \mathrm{~b}$ \\
\hline BNJ $5 \%$ & - & - & - & 0,63 & 1,82 & 2,57 \\
\hline
\end{tabular}

Pada Tabel 4, tampak bahwa jumlah akar terbanyak pada panjang stek yakni panjang stek $75 \mathrm{~cm}$ disemua umur. Sebaliknya jumlah akar terendah ada pada panjang stek $25 \mathrm{~cm}$ disemua umur. Hasil penelitian ini menunjukkan panjang stek pengaruh nyata terhadap jumlah dan panjang akar. Hal ini diduga adanya perbedaan cadangan makanan pada panjang stek yang berbeda, dengan demikian cadangan makanan yang berbeda pada stek akan menimbulkan pertumbuhan yang berbeda pula. Cadangan makanan yang terdapat dalam stek akan diolah atau dirombak oleh tanaman itu sendiri yang akan digunakan untuk membentuk atau merangsang pertumbuhan sel-sel jaringan tanaman (stek), yang pada akhirnya dapat mendukung aktivitas organ-organ pertumbuhan seperti tunas, batang dan akar (Alit et al., 2016).

Proses pembentukan akar pada tanaman dari hasil perbanyakan vegetatif dengan menggunakan stek batang berbeda dengan perbanyakan generatif yang menggunakan biji melalui pesemaian. Akar pada stek batang terbentuk secara adventif dari kambium dan bagian node (buku) yang ada pada batang. Akar pada stek batang terbentuk karena adanya 
pelukaan, dan akar terbentuk dari jaringan parenchym (Moko, 2004). Ditambahkan pula oleh Magingo et al. (2001), bahwa pertumbuhan akar pada stek batang dipengaruhi oleh kandungan karbohidrat dan panjang stek. Semakin panjang stek yang digunakan maka pertumbuhan panjang akarnya semakin baik karena lebih banyak cadangan makanan yang digunakan untuk mendukung pertumbuhan akarnya.

\section{Bobot Segar dan Bobot Kering Tunas}

Panjang stek berpengaruh nyata terhadap bobot segar dan bobot kering tunas bibit khusus pada saat umur 56 dan 84 HST, serta diameter stek berpengaruh tidak nyata terhadap kedua parameter tersebut khusus pada saat umur 56 dan 84 HST. Bobot segar dan bobot kering tunas disajikan pada Tabel 5.

Panjang stek $75 \mathrm{~cm}$ menghasilkan bobot segar tertinggi saat berumur 28, 56, dan 84 HST memiliki berat berturut-turut yakni 5,89, 95,90, dan 309,56 g. Hal ini disebabkan karena bahan awal stek yang berbeda panjangnya telah memiliki bobot segar yang berbeda pula. Selain itu, data dari pengamatan pada variabel panjang tunas menunjukkan bahwa panjang stek $75 \mathrm{~cm}$ menghasilkan tunas terpanjang, sehingga pada akhirnya akan mempengaruhi bobot segar dari bibit, sedangkan parameter bobot kering tunas saat umur 28 HST panjang stek berbeda tidak nyata pada semua perlakuan.

Tabel 5. Perkembangan bobot segar dan bobot kering tunas bibit kelor pada berbagai ukuran stek batang.

\begin{tabular}{|c|c|c|c|c|c|c|}
\hline \multirow{3}{*}{ Ukuran stek } & \multirow{2}{*}{\multicolumn{3}{|c|}{$\frac{\text { Bobot segar tunas }(\mathrm{g})}{\text { waktu pengamatan }(\mathrm{HST})}$}} & \multirow{2}{*}{\multicolumn{3}{|c|}{$\frac{\text { Bobot kering tunas }(\mathrm{g})}{\text { waktu pengamatan }(\mathrm{HST})}$}} \\
\hline & & & & & & \\
\hline & 28 & 56 & 84 & 28 & 56 & 84 \\
\hline \multicolumn{7}{|l|}{ Panjang stek (P) } \\
\hline $25 \mathrm{~cm}$ & 2,61 & $9,57 \mathrm{~b}$ & $20,85 \mathrm{c}$ & 0,13 & $0,91 \mathrm{~b}$ & $2,66 \mathrm{~b}$ \\
\hline $50 \mathrm{~cm}$ & 5,27 & $85,68 \mathrm{a}$ & $186,44 \mathrm{~b}$ & 0,47 & $13,83 \mathrm{a}$ & $34,79 \mathrm{a}$ \\
\hline $75 \mathrm{~cm}$ & 5,89 & $95,90 \mathrm{a}$ & 309,56 a & 0,80 & $14,01 \mathrm{a}$ & $51,22 \mathrm{a}$ \\
\hline BNJ $5 \%$ & - & 63,85 & 122,13 & - & 10,66 & 23,26 \\
\hline \multicolumn{7}{|l|}{ Diameter stek (D) } \\
\hline $3-4 \mathrm{~cm}$ & 4,55 & 58,23 & 138,63 & 0,61 & 8,42 & 22,96 \\
\hline $4,1-5 \mathrm{~cm}$ & 5,96 & 70,99 & 182,16 & 0,50 & 10,93 & 34,82 \\
\hline $5,1-6 \mathrm{~cm}$ & 3,26 & 61,93 & 196,07 & 0,27 & 9,40 & 30,90 \\
\hline BNJ $5 \%$ & - & - & - & - & - & - \\
\hline
\end{tabular}

Panjang stek batang $75 \mathrm{~cm}$ menghasilkan bobot kering tunas tertinggi saat berumur 28, 56, dan 84 HST yaitu berturut-turut seberat $0,80 \mathrm{~g}, 14,01 \mathrm{~g}$, dan 51,22 g. Hal ini dikarenakan bahan awal stek yang berbeda panjangnya telah memiliki bobot segar yang berbeda pula. Selain itu, juga diduga karena stek dengan panjang $75 \mathrm{~cm}$ lebih banyak tersusun dari jaringan dewasa sehingga kadar airnya sedikit. Menurut Sugeng (2005), jika fotosintesis berlangsung dengan baik, maka tanaman akan tumbuh dengan baik yang diikuti oleh berat kering tanaman yang mencerminkan status nutrisi tanaman, karena berat kering tanaman tersebut tergantung pada aktifitas sel, ukuran sel dan kualitas sel penyusun tanaman. 
Nampaknya bahwa panjang $75 \mathrm{~cm}$ sangat menunjang pembesaran ukuran sel yang menyebabkan peningkatan bobot kering tunas.

\section{Bobot Segar dan Bobot Kering Akar}

Ukuran panjang stek berpengaruh nyata terhadap bobot segar dan kering akar pada umur 56 dan 84 HST (Tabel 6). Pada Tabel 6 tampak bahwa bobot kering akar paling berat terdapat pada panjang stek $75 \mathrm{~cm}(4,44 \mathrm{~g})$ saat berumur 84 HST, sedangkan bobot kering akar paling ringan terdapat pada panjang stek $25 \mathrm{~cm}(0,08 \mathrm{~g})$ saat berumur $28 \mathrm{HST}$. Bobot kering akar merupakan akumulasi senyawa organik dan terkait dengan pertumbuhan panjang akar, semakin panjang akar maka akan menghasilkan bobot kering akar yang lebih besar (Sofyan et al., 2014). Bobot kering akar perlakuan panjang stek $75 \mathrm{~cm}$ lebih tinggi daripada panjang stek 50 dan $25 \mathrm{~cm}$. Fakta ini menunjukkan bahwa panjang stek $75 \mathrm{~cm}$ mampu meningkatakan bobot kering yang lebih baik dari panjang stek 50 dan $25 \mathrm{~cm}$. Hal ini berkaitan dengan fakta yang terungkap sebelumnya yaitu rata-rata jumlah akar tertinggi dimiliki oleh panjang stek $75 \mathrm{~cm}$, begitu juga rata-rata berat kering akar tertinggi dimiliki oleh panjang stek $75 \mathrm{~cm}$. Dengan demikian terlihat bahwa jumlah akar dan berat kering akar saling berkaitan, semakin banyak jumlah akarnya maka berat kering akarnya akan semakin tinggi pula (Nurhayati, 2000).

Tabel 6. Perkembangan bobot segar dan kering akar bibit kelor berbagai ukuran stek batang.

\begin{tabular}{|c|c|c|c|c|c|c|}
\hline \multirow[t]{2}{*}{ Ukuran stek } & \multicolumn{3}{|c|}{$\begin{array}{c}\text { Bobot segar akar }(\mathrm{g}) \\
\text { waktu pengamatan }(\mathrm{HST})\end{array}$} & \multicolumn{3}{|c|}{$\begin{array}{c}\text { Bobot kering akar }(\mathrm{g}) \\
\text { waktu pengamatan (HST) }\end{array}$} \\
\hline & 28 & 56 & 84 & 28 & 56 & 84 \\
\hline \multicolumn{7}{|l|}{ Panjang stek (P) } \\
\hline $25 \mathrm{~cm}$ & 0,18 & $0,46 \mathrm{~b}$ & $0,87 \mathrm{~b}$ & 0,08 & $0,12 \mathrm{~b}$ & $0,19 \mathrm{~b}$ \\
\hline $50 \mathrm{~cm}$ & 2,01 & $5,32 \mathrm{a}$ & $12,43 \mathrm{a}$ & 0,66 & $0,68 \mathrm{ab}$ & $2,63 \mathrm{ab}$ \\
\hline $75 \mathrm{~cm}$ & 1,87 & $6,66 \mathrm{a}$ & $21,56 \mathrm{a}$ & 0,39 & $1,20 \mathrm{a}$ & $4,44 \mathrm{a}$ \\
\hline BNJ 5\% & - & 3,63 & 10,07 & - & 0,85 & 2,48 \\
\hline \multicolumn{7}{|l|}{ Diameter stek (D) } \\
\hline $3-4 \mathrm{~cm}$ & 1,18 & 4,50 & 9,27 & 0,32 & 0,99 & 1,95 \\
\hline $4,1-5 \mathrm{~cm}$ & 1,94 & 4,66 & 11,95 & 0,70 & 0,54 & 2,22 \\
\hline $5,1-6 \mathrm{~cm}$ & 0,94 & 3,29 & 13,64 & 0,12 & 0,47 & 3,09 \\
\hline BNJ $5 \%$ & - & - & - & - & - & - \\
\hline
\end{tabular}

Keterangan : angka-angka yang diikuti dengan huruf yang sama pada kolom yang sama berbeda tidak nyata pada uji lanjut BNJ $5 \%$, HST= Hari Setelah Tanam

\section{Bobot Berangkasan Sebelum dan Setelah Tumbuh Bibit}

Ukuran panjang maupun diameter stek berpengaruh nyata terhadap bobot berangkasan sebelum dan setelah tumbuh bibit kelor. Bobot stek pada berbagai umur pengamatan disajikan pada Tabel 7.

Ukuran bahan stek seperti panjang dan diameter batang stek harus menjadi pertimbangan dalam perbanyakan secara vegetatif tanaman jarak pagar, karena ukuran bahan stek terkait dengan keberadaan bahan cadangan makanan, yang umumnya karbohidrat. Potensi cadangan makanan yang dimiliki masing-masing stek akan menentukan pertumbuhan dan perkembangan bibit. Ukuran diameter stek batang mencerminkan perbedaan tingkat ketuaan jaringan batang bahan stek. Semakin besar diameter semakin lanjut perkembangan 
jaringan stek tersebut atau semakin kecil diameter semakin muda jaringan. Sehubungan dengan perbedaan ukuran panjang yang diuji dalam suatu percobaan pada tanaman jarak pagar, maka bobot awal bahan stek masing-masing ukuran panjang berbeda nyata. Baik bobot segar maupun bobot kering awal bahan stek terendah ditunjukkan panjang stek $20 \mathrm{~cm}$, kemudian disusul panjang stek $25 \mathrm{~cm}$, dan panjang stek $30 \mathrm{~cm}$ (Santoso et al., 2008).

Tabel 7. Perkembangan bobot berangkasan sebelum tumbuh, 28, 56, dan 84 HST, setelah tumbuh tunas bibit kelor pada berbagai ukuran stek batang.

\begin{tabular}{lcccc}
\hline \multirow{2}{*}{ Ukuran stek } & \multicolumn{4}{c}{ Bobot berangkasan stek $(\mathrm{g})$} \\
\cline { 2 - 5 } & 0 & \multicolumn{4}{c}{ waktu pengamatan $(\mathrm{HST})$} \\
\cline { 2 - 5 } & & 28 & 56 & 84 \\
\hline Panjang stek (P) & $360,80 \mathrm{c}$ & $375,90 \mathrm{c}$ & $414,60 \mathrm{c}$ & $457,90 \mathrm{c}$ \\
$25 \mathrm{~cm}$ & $763,90 \mathrm{~b}$ & $799,90 \mathrm{~b}$ & $831,70 \mathrm{~b}$ & $873,20 \mathrm{~b}$ \\
$50 \mathrm{~cm}$ & $1219,60 \mathrm{a}$ & $1285,20 \mathrm{a}$ & $1315,30 \mathrm{a}$ & $1347,40 \mathrm{a}$ \\
$75 \mathrm{~cm}$ & 40,63 & 80,20 & 81,05 & 68,17 \\
\hline BNJ 5\% & & & & \\
\hline Diameter stek (D) & $481,80 \mathrm{c}$ & $522,80 \mathrm{c}$ & $560,70 \mathrm{c}$ & $596,90 \mathrm{c}$ \\
$3-4 \mathrm{~cm}$ & $772,90 \mathrm{~b}$ & $799,80 \mathrm{~b}$ & $826,80 \mathrm{~b}$ & $860,70 \mathrm{~b}$ \\
$4,1-5 \mathrm{~cm}$ & $1089,60 \mathrm{a}$ & $1138,40 \mathrm{a}$ & $1174,10 \mathrm{a}$ & $1221,0 \mathrm{a}$ \\
$5,1-6 \mathrm{~cm}$ & 40,63 & 80,20 & 81,05 & 68,17 \\
\hline BNJ 5 \% & & &
\end{tabular}

Keterangan : angka-angka yang diikuti dengan huruf yang sama pada kolom yang sama berbeda tidak nyata pada uji lanjut BNJ $5 \%$, HST= Hari Setelah Tanam.

\section{Bobot Berangkasan Sebelum dan Setelah Tumbuh Bibit pada Berbagai Kombinasi}

Macam kombinasi stek batang berpengaruh nyata terhadap peningkatan bobot berangkasan sebelum dan setelah tumbuh bibit kelor hingga umur tiga bulan. Bobot stek pada berbagai umur pengamatan disajikan pada Tabel 8 .

Tabel 8. Perkembangan bobot berangkasan sebelum tumbuh, 28, 56, dan 84 HST sesudah tumbuh tunas bibit kelor pada berbagai kombinasi perlakuan stek batang.

\begin{tabular}{|c|c|c|c|c|c|}
\hline \multirow{3}{*}{\multicolumn{2}{|c|}{$\begin{array}{c}\text { Kombinasi Ukuran } \\
\text { Stek }\end{array}$}} & \multicolumn{4}{|c|}{ Bobot berangkasan basah stek (g) } \\
\hline & & \multicolumn{4}{|c|}{ waktu pengamatan (HST) } \\
\hline & & 0 & 28 & 56 & 84 \\
\hline \multicolumn{6}{|c|}{ Panjang Diameter } \\
\hline 25 & $3-4$ & $231,00 \mathrm{~g}$ & $236.70 \mathrm{~g}$ & $274.00 \mathrm{~g}$ & $321.70 \mathrm{f}$ \\
\hline 25 & $4,1-5$ & $337,70 \mathrm{f}$ & $353.00 \mathrm{fg}$ & $396.30 \mathrm{fg}$ & $430.70 \mathrm{f}$ \\
\hline 25 & $5,1-6$ & $513,70 \mathrm{e}$ & 538.00 ef & 573.30 ef & $621.30 \mathrm{e}$ \\
\hline 50 & $3-4$ & $505,70 \mathrm{e}$ & $566.30 \mathrm{e}$ & $615.00 \mathrm{de}$ & $658.00 \mathrm{de}$ \\
\hline 50 & $4,1-5$ & $751,00 \mathrm{~d}$ & $765.00 \mathrm{~d}$ & $776.70 \mathrm{~d}$ & $800.30 \mathrm{~d}$ \\
\hline 50 & $5,1-6$ & $1035,00 \mathrm{c}$ & $1068.30 \mathrm{c}$ & $1103.30 \mathrm{c}$ & $1161.30 \mathrm{c}$ \\
\hline 75 & $3-4$ & $708,70 \mathrm{~d}$ & $765.30 \mathrm{~d}$ & $793.00 \mathrm{~d}$ & $811.00 \mathrm{~d}$ \\
\hline 75 & $4,1-5$ & $1230,00 \mathrm{~b}$ & $1281.30 \mathrm{~b}$ & $1307.30 \mathrm{~b}$ & $1351.00 \mathrm{~b}$ \\
\hline 75 & $5,1-6$ & $1720,00 \mathrm{a}$ & $1809.00 \mathrm{a}$ & $1845.70 \mathrm{a}$ & $1880.30 \mathrm{a}$ \\
\hline \multicolumn{2}{|c|}{ BNJ $5 \%$} & 70,37 & 138,91 & 140,39 & 118,07 \\
\hline
\end{tabular}

Keterangan : angka-angka yang diikuti dengan huruf yang sama pada kolom yang sama berbeda tidak nyata pada uji lanjut BNJ $5 \%$, HST= Hari Setelah Tanam 
Kombinasi perlakuan panjang dan diameter stek menunjukkan adanya interaksi antara berbagai bobot brangkasan stek saat awal, 28, 56, dan 84 HST dari stek batang kelor. Pengaruh tersebut nampak diduga disebabkan sebagai respon kedewasaan jaringan bahan stek. Semakin banyak karbohidrat yang tersedia pada bahan stek, maka pembentukan akar serta tunas akan lebih mudah (Santoso, 2009). Dengan demikian dapat dikatakan perbedaan yang nyata antara kombinasi perlakuan panjang dan diameter stek, berhubungan dengan jumlah karbohidrat yang tertimbun dalam jaringan bahan stek.

Perlakuan kombinasi Panjang stek $75 \mathrm{~cm}$ dan diameter stek 5,1-6 cm menunjukkan pertumbuhan bibit kelor paling baik dibandingkan dengan perlakuan lainnya karena karakteristik pembibitan tanaman dengan stek menyimpan cadangan makanan pada bagian batang tanaman sebelum akar tumbuh. Bagian ini mampu memacu percepatan pertumbuhan tunas tanaman sehingga semakin panjang bahan stek akan semakin cepat pula pertumbuhannya. Hasil penelitian ini sejalan dengan pendapat Emil (2011), yang menyatakan bahwa kualitas stek buah naga dipengaruhi oleh umur tanaman dan diameter batang.

\section{KESIMPULAN}

Kombinasi panjang stek $75 \mathrm{~cm}$ dan diameter stek 5,1-6 cm menghasilkan bibit yang baik yang ditunjukkan oleh bobot berangkasan bibit tertinggi. Semakin panjang stek $(75 \mathrm{~cm})$ pertumbuhan stek semakin baik, dan semakin tebal diameter stek $(5,1-6 \mathrm{~cm})$ menghasilkan bobot berangkasan bibit tertinggi. Namun demikian, dalam rangka penyediaan bibit kelor bagi usaha pengembangannya penggunaan stek batang dengan panjang $50-75 \mathrm{~cm}$, dengan diameter 3-4 cm hingga 4,1-5 cm dapat dijadikan pilihan.

Ucapan terima kasih: disampaikan kepada Kemenristekdikti atas pendanaan pelaksanaan penelitian ini melalui skim Penelitian Produk Terapan (Desentralisasi Perguruan Tinggi) dengan nomer kontrak 074/SP2H/LT/DRPM/IV/2017.

\section{DAFTAR PUSTAKA}

Alit, K.G.K., Andi, E., Hamid, N. 2016. Pengaruh Berbagai Jenis Pupuk Organik pada Panjang Stek yang Berbeda Terhadap Pertumbuhan Bibit Buah Naga (Hylocereus costaricensis). e-J. Agrotekbis. 4 (6): 675-683.

Emil, S. 2011. Untung Berlipat dari Bisnis Buah Naga Unggul. Lily Publisher. Yogyakarta.

Hartman, H.T., Kester, D.E., Davies, F.T., Geneve, Jr. R.L. 2002. Plant Propagation: Principles and Practices. $7^{\text {th }}$ edition. Prentice Hall Inc. Hal.770.

Hidayanto, M., Nurjanah, S., Yossita, F. 2003. Pengaruh Panjang Stek Akar dan Konsentrasi Natrium-nitrofenol terhadap Pertumbuhan Stek Akar Sukun (Artocarpus communis F.). Jurnal Pengkajian dan Pengembangan Teknologi Pertanian 6 (2): 66-80.

Magingo, F.S.S., Dick, J.M.C.P. 2001. Propagation of Two Miombo Woodland Trees by Leafy Stem Cuttings Obtained from Seedlings. Agroforestry Systems 51: 49-55.

Moko, H. 2004. Teknik Perbanyakan Tanaman Hutan Secara Vegetative. Informasi Teknis 2(1): $1-20$. 
Nurhasybi., Danu., Dede, J.S., Dharmawati, F.D. 2003. Kajian Komprehensif Benih Tanaman Hutan Jenis-Jenis Dipterocarpaceae. Balai Penelitian dan Pengembangan Teknologi Perbenihan. Bogor.

Nurhayati, A.D. 2000. Pengaruh Bahan Stek dan Rootone F Terhadap Pertumbuhan Stek Seuseureuhan (Piper aduncum Linn.). [Skripsi]. Fakultas Kehutanan, Institut Pertanian Bogor. Bogor. Indonesia.

Raden, I. 2008. Studi Arsitektur Tajuk Jarak Pagar (Jatropha curcas L.) Hubungannya dengan Kapasitas Fotosintesis, Produksi dan Kandungan Minyak. [Disertasi Program Pascasarjana]. Institut Pertanian Bogor. Bogor. Indonesia.

Santoso, BB. 2009. Pembiakan Vegetatif dalam Hortikultura. Unram Press. Mataram.

Santoso, BB., Hasnam., Hariyadi., Susanto S., Bambang SP. 2008. Perbanyakan Vegetatif Tanaman Jarak Pagar (Jatropha curcas L.) dengan Stek Batang: Pengaruh Panjang dan Diameter Stek. Bul. Agron. 36(3): 255-262.

Setiyawan, A. 2000. Pengaruh Pemberian Pupuk Kandang Ayam pada Transplanting Setek Cabang 1 Buku dan 2 Buku Bambu Ampel Hijau. [Skripsi]. Fakultas Pertanian. Institut Pertanian Bogor. Bogor. Indonesia.

Sofyan, A., Nurjaya, Kasno A. 2014. Status Hara Tanah Sawah Untuk Rekomendasi Pemupukan. Dalam: Tanah Sawah dan Teknologi Pengelolaannya. Pusat Penelitian dan Pengembangan Tanah dan Agroklimat. Bogor.

Sugeng, W. 2005. Kesuburan Tanah (Dasar-Dasar Kesehatan dan Kualitas Tanah). Gava Media: Yogyakarta. 